\title{
哝iresalce
}

\section{A mobile app as an educational and motivational tool for adolescents in} orthodontic practice

\author{
APLICATIVO MÓVEL: FERRAMENTA EDUCACIONAL E MOTIVACIONAL PARA \\ ADOLESCENTES NA PRÁTICA ORTODÔNTICA
}

Ana Patrícia Broxado Schettini Barretto', Silvia A. S. Vedovello2,

Heloísa Cristina Valdrighi3 ${ }^{3}$ Marcelo de C. Meneghim ${ }^{4}$, Milton Santamaria-Jr ${ }^{5}$

\author{
1 Mestre em Ortodontia. Programa de Pós-graduação \\ em Ortodontia, Fundação Hermínio Ometto - FHO. \\ ORCID: https://orcid.org/0000-0002-8244-2405 \\ Email: broxado@hotmail.com \\ 2 Doutora em Ortodontia. Programa de Pós- \\ graduação em Ortodontia, Fundação Hermínio \\ Ometto - FHO. \\ ORCID: https://orcid.org/0000-0002-7203-2867 \\ Email: silviavedovello@gmail.com \\ 3 Doutora em Ortodontia. Programa de Pós- \\ graduação em Ortodontia, Fundação Hermínio \\ Ometto - FHO. \\ ORCID: https://orcid.org/0000-000 1-7567-1990 \\ Email: heloisavaldrighi@gmail.com \\ 4 Doutor em Odontologia Preventiva e Social. \\ Departamento Ciências da Saúde e Odontologia \\ Infantil, Faculdade de Odontologia de Piracicaba. \\ ORCID: https://orcid.org/0000-0003-2673-3627 \\ Email: meneghim@fop.unicamp.br \\ 5 Doutor em Patologia Bucal. Programa de Pós- \\ graduação em Ortodontia, Fundação Hermínio \\ Ometto - FHO. \\ ORCID: https://orcid.org/0000-0002-3490-5030 \\ Email: santamariajr@ig.com.br
}

Correspondência: Centro Universitário da Fundação Hermínio Ometto-FHO Dr. Maximiliano Baruto, 500. Araras-SP, Brasil. CEP.13607-339.

Copyright: Esta obra está licenciada com uma Licença Creative Commons Atribuição-NãoComercial 4.0 Internacional.

Conflito de interesses: os autores declaram que não há conflito de interesses.

\section{Como citar este artigo}

Barreto APBS; Vedovelho SAS; Valdrighi HC; Meneghim M de C; Santamaria Jr. M. A mobile app as an educational and motivational tool for adolescents in orthodontic practice. Revista de Saúde Digital e Tecnologias Educacionais. [online], volume 5, n. 2. Editor responsável: Luiz Roberto de Oliveira. Fortaleza, julho de 2020, p. 04-13. Disponível em: http://periodicos.ufc.br/resdite/index. Acesso em "dia/mês/ano".

Data de recebimento do artigo: 09/02/2020

Data de aprovação do artigo: 24/06/2020

Data de publicação: 21/07/2020

\begin{abstract}
Objective: To evaluate the acceptance of the mobile application ("app") by adolescents in orthodontic treatment for a better applicability of this resource. Methods: Ninety orthodontic patients, aged between 13 and 17, of both sexes, used an application, chosen for presenting a Portuguese version and reaching the target audience. Then they registered their acceptance through the SUS (System Usability Scale) questionnaire, which measures user satisfaction through ease of use of the application, with its Satisfaction and Usability Indexes. The findings were subjected to descriptive and comparative statistical analysis using the Kruskal Wallis and Dunn test, adopting a significance level of $5 \%$.
\end{abstract}


Results: The application presented the aboveaverage Satisfaction and Usability Index (79.1). The domain (quality component) with the highest index was "Learnability" $(85,3)$, in relation to "Efficiency" $\quad(79,0), \quad$ "Satisfaction" $\quad(76,0)$, "Memorability" (72,2) and "Errors" $(71,4)(p \leq 0,05)$. Conclusion: Mobile app was accepted by adolescents in orthodontic treatment due to the ease and speed that it was used. However, its acceptance was negatively influenced by the reported frequency of use. Therefore, its application as an educational and motivational tool in clinical practice is suggested, as long as the different aspects that involve its best applicability are considered.

Keywords: Orthodontic, Education, Mobile app.

\section{Resumo}

Objetivo: Avaliar a aceitação do aplicativo móvel ("app") por adolescentes em tratamento ortodôntico para uma melhor aplicabilidade deste recurso. Material e Métodos: 90 pacientes em tratamento ortodôntico, com idades entre 13 e 17 anos, de ambos os sexos, utilizaram um aplicativo, escolhido por apresentar versão em português e ser direcionado para este público. Registrou-se a aceitação do app por meio do questionário SUS (System Usability Scale), que mensura a satisfação dos usuários pela facilidade de uso do aplicativo, com seus índices de Satisfação e Usabilidade. Esses achados foram submetidos a análises estatísticas descritivas e comparativas usando o teste de Kruskal Wallis e Dunn, adotando um nível de significância de 5\%. Resultados: Índice de Satisfação e Usabilidade acima da média $(79,1)$. O domínio (componente de qualidade) com maior índice foi "Capacidade de aprendizagem" $(85,3)$, em relação à "Eficiência"

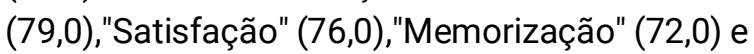
"Erros" $(71,4)(p \leq 0,05)$. A questão da frequência, no domínio "Satisfação", apresentou o menor índice $(63,0)$. Conclusão: 0 aplicativo móvel foi aceito pelos adolescentes em tratamento ortodôntico devido à facilidade e rapidez com a qual foi utilizado. No entanto, sua aceitação foi influenciada negativamente pela frequência de uso relatada. Portanto, sugere-se sua aplicação como ferramenta educacional e motivacional na prática clínica, desde que sejam considerados os diferentes aspectos que envolvem sua melhor aplicabilidade.

Palavras-chave: Ortodontia, Educação, Aplicativos móveis.

\section{Introdução}

The use of mobile technology by society has led to a new level of information delivery and interactivity with its users in various areas and this technology is being increasingly employed in clinical settings ${ }^{1,2}$. The popularization of smartphones, together with the proliferation of mobile apps, has contributed to this development ${ }^{3,4}$. Features such as portability, simplicity, possibility of upgrading, and speed allow for quick access to information, a fundamental quality for healthcare provision ${ }^{1,2,3,5}$.

For today's generation of adolescents, known as generation Z (zappers), the advantage of smartphone apps over traditional health management approaches is that they offer an interactive, social, and personalized platform to help them modify their own behavior with minimal professional contact ${ }^{6-8}$. Born into the digital age, these adolescents do everything very fast and simultaneously ${ }^{1}$. Their relationship with mobile devices is almost 
emotional, a good indicator of the effectiveness of motivational actions through specific $\operatorname{apps}^{2,9}$.

Mobile apps can facilitate communication and can be used as a motivational tool,1013. Educational information on malocclusion, types of treatment, oral hygiene, appliance care or even recall methods, remembering the consultation and the use of removable appliances or accessories such as intermaxillary elastic bands, make the patient more committed, which is essential for the success of treatment ${ }^{5,14-16}$. Nevertheless, the app needs to be easy to use $^{4,17}$ so that users feel satisfied and express their interest in its utilization ${ }^{3,18,19}$.

The usability of a system can be evaluated based on five domains or components of product quality ${ }^{17,20}$ : learnability (ease of using the system for the first time); efficiency (speed of performing the tasks); memorability (how easy it is to remember the use of the system after a period of not using it); errors (absence of errors in the system); satisfaction (pleasant design). Although subjective, these features can be evaluated through questionnaires. One such questionnaire is the System Usability Scale (SUS) ${ }^{3,9}$, which measures user satisfaction by evaluating usability of the product and thus its acceptance ${ }^{18,21,22}$.

Adolescents undergoing orthodontic treatment are encouraged by the application and this usability influences its use. Therefore, the aim of this study was to evaluate the acceptance of a mobile app by adolescents undergoing orthodontic treatment to improve the applicability of this tool.

\section{Métodos}

The Ethics Committee (CAAE 67248217.1.0000.5385) approved the study. A crosssectional, observational study was conducted on adolescents of both sexes aged 13 to 17 years. The criteria for inclusion were consent of the parents/legal representative (free informed consent form), having a smartphone (Android or iOS), and undergoing corrective orthodontic treatment. The total sample size of 90 adolescents, without loss, allowed estimation of the user satisfaction index (SUS) with a low sample error (2.3\%) for a confidence level of 95\% (R Core Team, R Foundation for Statistical Computing, Vienna, Austria, 2017).

The participants were recruited by five previously calibrated volunteer orthodontists. These professionals received a video that clearly and illustratively described the objective of the research, as well as the sequence of application of the method. In addition, this video 
was shared with patients at the time of the initial approach. The patients were informed about the installation of a specific app (BraceMate ${ }^{T M}$, Australia, 2014) on their smartphones during a routine visit. In the next visit, the participants answered the SUS developed by Brooke (1986).

The BraceMate ${ }^{\mathrm{TM}}$ app was chosen because it attends the target population ${ }^{1}$. The app is available free of charge in Portuguese for the Android and iOS operating systems and provides educational information on orthodontic care with interactive images for the customization of braces. In addition, a recent upgrade is available and the app has good ratings by internet users

The SUS is used to evaluate the perceived usability of the app by assessing user's satisfaction ${ }^{19}$. The questionnaire consists of 10 closed questions answered on a Likert scale to measure subjective perceptions in a quantitative manner and it has already been translated to Portuguese and validated ${ }^{23}$. Acceptance of the app by users is established based on the score achieved ${ }^{18,22}$. The satisfaction index ranges from 0 to 100 and an average score of 70 is considered acceptable ${ }^{21}$. Each question is rated on a scale from 1 to 5 , where 1 means "I do not agree at all" and 5 means "I agree completely". For odd-numbered questions, 1 is subtracted from the user's response. For even-numbered questions, the user's score is subtracted from 5 . Finally, the sum of the scores of the 10 questions is multiplied by 2.5 to obtain the overall user satisfaction ${ }^{19}$.

The following domains are associated with usability of the app evaluated by the SUS questions, as shown in Table 1: "learnability" corresponding to the average index of the sum of questions 3, 4, 7 and 10; "efficiency" obtained as the sum of questions 5, 6 and 8; "memorability" corresponding to the index of question 2; "errors" corresponding to the index of question 6, and "satisfaction" obtained as the sum of questions 1, 4 and 919,21,23.

The data were analyzed based on the SUS questions, followed by the domains. First, descriptive analysis of the SUS scores was performed and the Kruskal-Wallis and Dunn tests were used for comparison of the findings. The SAS (SAS Institute, Inc., Cary, NC, USA; Release 9.2, 2010) and R programs (R Core Team, R Foundation for Statistical Computing, Vienna, Austria, 2015) were used for analysis, adopting a level of significance of $5 \%$.

\section{Resultados}

Figure 1 shows the analysis of the SUS questions. The app exhibited a satisfaction index above the average score of 70 . The highest satisfaction indices were obtained for 
questions 3 (I thought the app was easy to use), 4 (I think I would need the help of a person with technical knowledge to use the app), and 8 (I found the app complicated to use), which were the items that most positively influenced this finding. On the other hand, question 1 (I would like to use this app frequently) had a negative influence, with an index below the average $(p \leq 0.05)$.

Figure 2 shows the domain results. The "learnability" domain obtained the highest satisfaction index, being significant when compared to the other domains, followed by the "efficiency" domain ( $p \leq 0.05)$.

\section{Discussion}

Mobile technology can be considered an ally in current orthodontic clinical practice, improving the education, communication and motivation of adolescent patients $1,5,8,11,16$. On the other hand, this technology is challenging for professionals who need to understand the acceptance of this resource in order to better use $\mathrm{it}^{15,24}$. Our findings showed the acceptance of such resources based on the evaluation of the usability of the app tested. The results suggest a promising application of this tool to the treatment of adolescent patients in orthodontics.

The positive perception of the app by adolescents undergoing orthodontic treatment was demonstrated by the SUS questionnaire, which showed satisfaction of these users and acceptance of the $\mathrm{app}^{21}$. The SUS is one of the most accepted questionnaires for measuring product usability because of its standardization, reliability, and validity ${ }^{17}$. In addition, many authors agree that this questionnaire is the most practical, rapid and least costly tool to test the approval of an app ${ }^{18,21}$, although others believe it is not sufficient and complement testing using more exploratory techniques that require computer laboratories ${ }^{3,9}$.

The dissemination of smartphones and mobile apps across different social classes allows these tools to be used on a large scale by orthodontists for the education and motivation of their patients ${ }^{15}$. The fact that participants in this study used the app without hindrance, hesitation or questions also confirms the ISO 9241-11 standard and the expert literature which consider usability to be one of the most important quality attributes of smartphone apps $7,17,24$.

Most patients agreed that the functions of the app were well integrated and disagreed regarding the presence of inconsistency and complication to use it. According to specialists, these attributes increase the speed of performing the tasks ${ }^{7,20}$. As reported in the literature, 
it is not sufficient to meet only the technical requirements and functionalities for which the application was designed, but users demand that it be easy to use and quick to learn ${ }^{24}$ as observed in this study.

In another study, adolescents indicated that social influence is also an important facilitator for the adoption and use of apps by reporting that they were more likely to try a specific app if it is recommended by a friend, professional, celebrity or social networks ${ }^{7}$. Furthermore, social media can efficiently propagate audiovisual information to orthodontic patients, increasing treatment adherence among adolescents $\mathbf{s}^{11,13,24}$.

Special attention should be paid to error prevention mechanisms so that the user does not choose an invalid option and only receives an error message, which could cause frustration ${ }^{24}$. In the case of this app, the displayed information and interface functions had the same visual presentation, minimizing the possibility of errors ${ }^{7}$. There were also no major problems when the app was used after a period of not using it, resulting in user satisfaction ${ }^{24}$.

On the other hand, the satisfaction of the participants was negatively influenced by the usage frequency question. According to the literature, satisfaction is linked to the absence of discomfort and the presence of positive attitudes associated with the use of an app, which are detected by recording the usage frequency, safety, confidence and praise made by the patients, who were found to be satisfied 9 .

Thus, improvements are necessary to maintain the interest in using the app. Intrinsic motivation seems to be an important factor among adolescent users. Studies recommend the inclusion of tangible rewards to attract users, such as gift cards, app store credits or virtual points, which may be associated with games ${ }^{12,16}$. In the digital age, which is characterized by adolescents spending a lot of their time using text messaging and social networks, watching videos and playing games, healthcare apps need to be fun so that adolescents actually keep using them. Customization of the app is also suggested, allowing its personalization by setting goals, tracking personal data and customizing messages ${ }^{7,24}$.

Another factor that can compromise the usage frequency in this case is the interface design and multimedia content. Visually appealing apps with vibrant colors, bold graphics, animation clips and videos usually raise the interest of healthcare app users and make the apps more enjoyable to use, increasing their usage frequency ${ }^{7,16,24}$. This also suggests the need for specific professionals from the area of technological development alongside orthodontists for the development of these adds, increasing the quality of use of the end product ${ }^{8}$. 
One limitation of this study is the application of the method to patients with different levels of motivation because they were at the beginning or end of orthodontic treatment and due to the presence of pain, discomfort or even differences in esthetic appearance ${ }^{25}$.

The age and sex of the users, as well as the number of accesses to the app during the available period, are variables that can also be evaluated. However, the sample size of this study was too small to evaluate the associations between acceptance of the app and these factors. Thus, further studies are needed to ensure a better applicability of current educational and motivational tools.

\section{Conclusão}

The mobile app was accepted by adolescents undergoing orthodontic treatment due to its ease of use and speed, suggesting its application as an educational and motivational tool in orthodontic clinical practice. However, its acceptance was negatively influenced by the reported frequency of use. Therefore, its application as an educational and motivational tool in clinical practice is suggested, as long as the different aspects that involve its best applicability are considered.

\section{Referências}

1. Singh P. Orthodontic apps for smartphones. Journal of Orthodontics 2013; 40 (3): 249-255.

2. Underwood B, Birdsall J, Kay E. The use of a mobile app to motivate evidence-based oral hygiene behaviour. British Dental Journal 2015; 219 (E2).

3. Kortum P, Sorber M. Measuring the Usability of Mobile Applications for Phones and Tablets. International Journal of Human-Computer Interaction 2015; 31 (8): 518529.

4. Tiffany B, Blasi P, Catz SL, McCluree JB. Mobile Apps for Oral Health Promotion: Content Review and Heuristic Usability Analysis. JMIR Mhealth Uhealth 2018; 6 (9): e11432.

5. Chan A, Kow R, Cheng JK. Adolescents' perceptions on smartphone applications (apps) for health management. Journal of Mobile Technology In Medicine 2017; 6 (2): 47-55.

6. Baheti MJ, Toshniwal N. Orthodontic apps at fingertips. Progress in Orthodontics 2014; 15 (36).

7. Zotti F, Dalessandri D, Salgarello S, Piancino M, Bonetti S, Visconti L, Paganelli C. Usefulness of an app in improving oral hygiene compliance in adolescente orthodontic patients. Angle Orthodontist 2016; 86 (1): 101-107.

8. Scheerman JFM, van Empelen P, van Loveren C, van Meijel B. A Mobile App (White Teeth) to promote good oral behavior among dutch adolescents with fixed 
orthodontic appliances: intervention mapping approach. JMIR Mhealth Uhealth 2018; 6 (8):163.

9. Grindrod KH, Hengartner U, Ong S, Logan AG, Vogel D, Gebotys R, Yang J. Evaluating authentication options for mobile health applications in younger and older adults. PLoS ONE 2018; 13 (1).

10. Henzell M, Knight A, Antoun JS, Fareella M. Social media use by orthodontic patients. New Zealand Dental Journal 2013; 109 (4): 130-3.

11. Li X., Xu ZR, Tang N, Ye C, Zhu X, Zhou T, Zhao ZH. Effect of intervention using a messaging app on compliance and duration of treatment in orthodontic patients. Clinical Oral Investigations 2016; 20 (8): 1849-1859.

12. Wright NS; Fleming PS; Sharma PK; Battageld J. Influence of Supplemental Written Information on Adolescent Anxiety, Motivation and Compliance in Early Orthodontic Treatment. Angle Orthodontist 2010; 80 (2): 329-335.

13. Al-Silwadi FM, Gill DS, Petrie A, Cunningham SJ. Effect of social media in improving knowledge among patients having fixed appliance orthodontic treatment: A singlecenter randomized controlled trial. American Journal of Orthodontics and Dentofacial Orthopedics 2015; 148 (2), 231-237.

14. Aljabaa A, McDonaldb F, Newton JT. A systematic review of randomized controlled trials of interventions to improve adherence among orthodontic patients aged 12 to 18. The Angle Orthodontist 2015; 85 (2): 305-313.

15. Tantawi ME, Bakhurji E, Al-Ansari A, AlSubaie A, Al Subaie HÁ, A AlAli. Indicators of adolescents' preference to receive oral health information using social media. Acta Odontologica Scandinavica 2019; 77 (3): 213-218.

16. Lodha S, Mehta S, Agarwal R. A “Smart" Elastics Reminder. JCO - Journal of Clinical Orthodontics 2014; 48 (3):180.

17. Alkadhi $\mathrm{OH}$, Zahid MN, Almanea RS, Althaqeb HK, Alharbi TH, Ajwa NM. The effect of using mobile applications for improving oral hygiene in patients with orthodontic fixed appliances: a randomised controlled trial. Journal of Orthodontics 2017; 44 (3): 157-163.

18. Peres SC, Pham t, Phillips R. Validation of the system usability scale (sus): SUS in the wild. SAGE Journals 2013; 57 (1): 192-196.

19. Brooke J. SUS: A Retrospective. JUS - Journal of Usability Studies 2013; 8 (2): 2940.

20. Sousa P, Fonseca H, Gaspar P, Gaspar F. Usability of an internet-based platform (Next.Step) for adolescent weight management. J Pediatric (Rio J). 2015; 91: 68-74.

21. Nielsen J. Usability 101: introduction to usability 2003. Disponível em <http://www.useit.com/alertbox/20030825.html>. Acesso em: 27 set. 2016.

22. Bangor A, Kortum P, Miller J. Determining What Individual SUS Scores Mean: Adding na Adjective Rating Scale. JUS - Journal Of Usability Studies 2009 maio; 4 (3):114123.

23. Tenorio JM, Sdepanian VL, Pisa IT, Cohrs FM, Marin HF. Desenvolvimento e Avaliação de um Protocolo Eletrônico para Atendimento e Monitoramento do Paciente com Doença Celíaca. RITA 2010; 17 (2): 210-220.

24. Peng W, Kanthawala S, Yuan S, Hussain SA. A qualitative study of user perceptions of mobile health apps. BMC Public Health 2016; 16(1): 1-11.

25. Daniels AS, Seacat JD, Inglehart MR. Orthodontic treatment motivation and cooperation: A cross-sectional analysis of adolescent patients' and parents' responses. American Journal of Orthodontics and Dentofacial Orthopedics 2009; 136 (6): 780-7. 


\section{Anexos}

Figure 1. Average satisfaction index (System Usability Scale) according to question. Questions with different uppercase letter differ from one another. Kruskal-Wallis and Dunn tests $(p \leq 0.05)$.

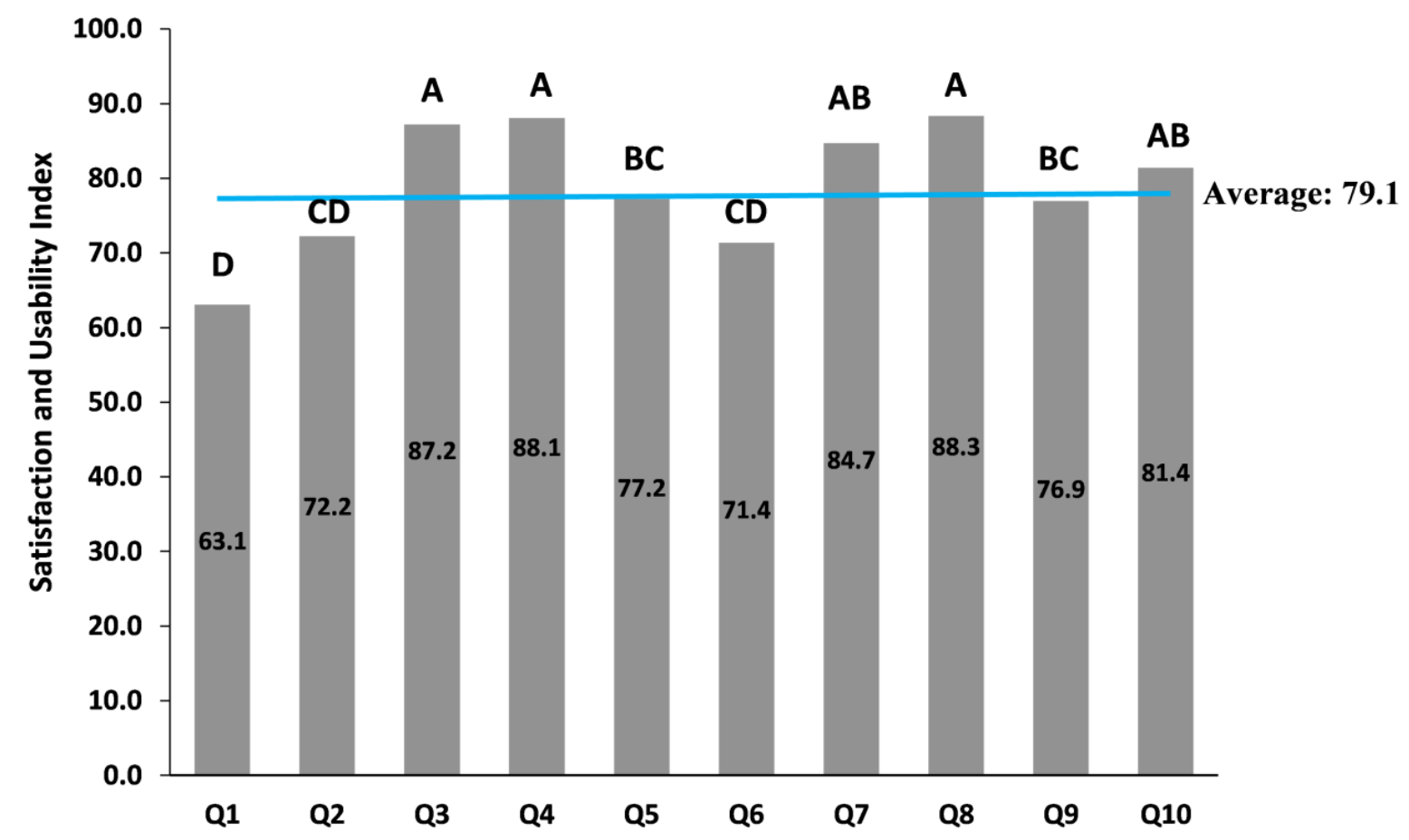

Fonte: Autoria própria. 
Figure 2. Average satisfaction index (System Usability Scale) according to domain. Domains with different uppercase letters differ from one another. Kruskal-Wallis and Dunn tests $(p \leq 0.05)$.

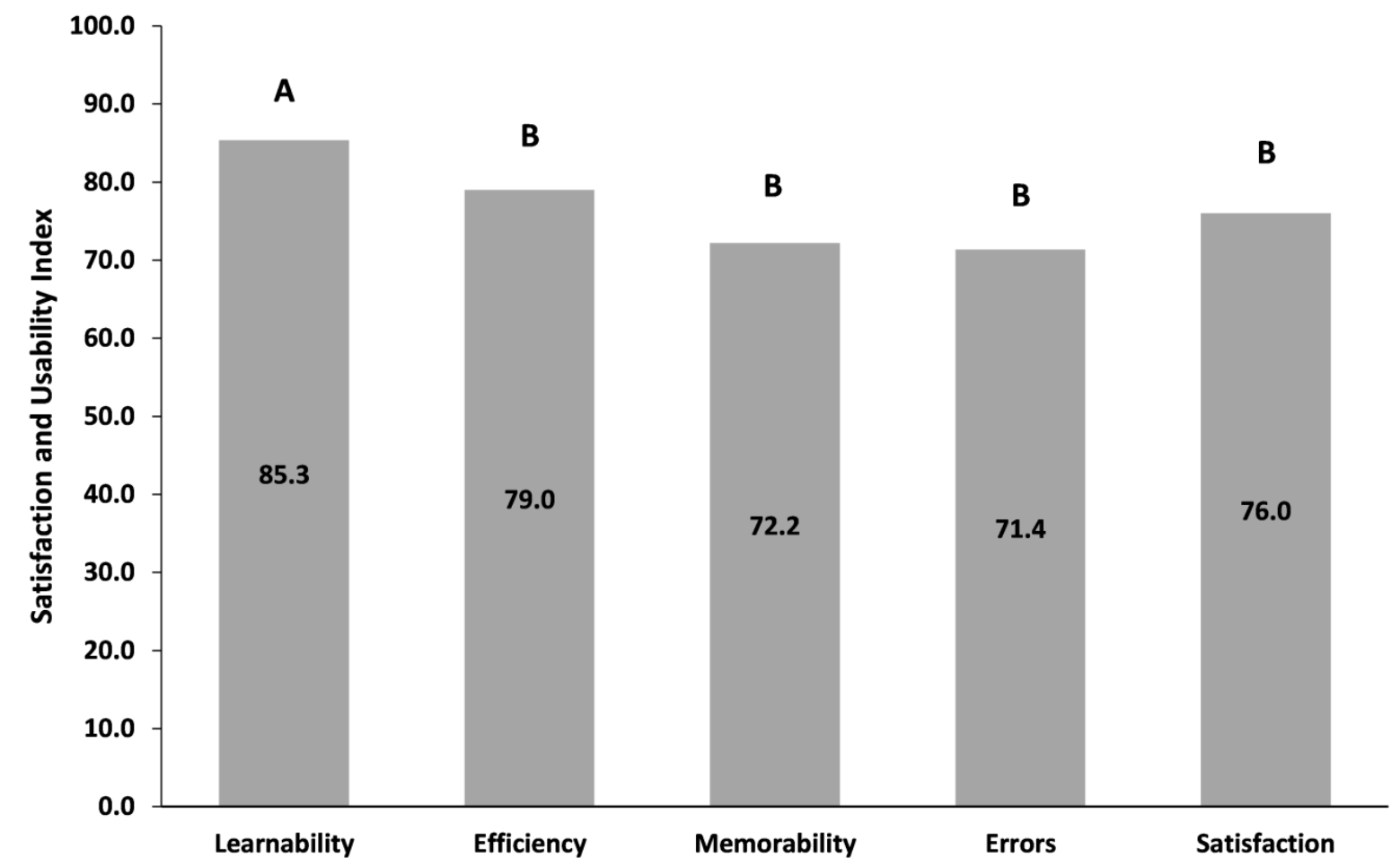

Fonte: Autoria própria. 